\title{
Enhanced Production of Lipid as Biofuel Feedstock from the Marine Diatom Nitzschia sp. by Optimizing Cultural Conditions
}

\begin{abstract}
Anandapadmanaban Baala Harini, ${ }^{\text {a }}$ Renganathan Rajkumar, ${ }^{\text {a,* }}$ and Mohd Sobri Takriff ${ }^{\mathrm{b}, *}$

Microalgae were isolated, identified, and cultivated for enhanced biomass production and lipid accumulation. A marine microalgae was isolated from coastal rock pools of Tuticorin, Tamil Nadu, and identified as Nitzschia sp. RRSE2 upon microscopic examination and molecular sequence analysis. The experimental results showed that the maximum growth, biomass, and lipid content were obtained at $\mathrm{pH} 8$ using the $\mathrm{F} / 2$ medium. These parameters revealed a notable difference when $\mathrm{NaCl}$ was added at $3 \%$ concentration. Meanwhile, the nutrients $\mathrm{NaNO}_{3}\left(18.75 \mathrm{mgL}^{-1}\right)$ and $\mathrm{NaH}_{2} \mathrm{PO}_{4}\left(3.48 \mathrm{mgL}^{-1}\right)$ were shown to be suitable nitrogen and phosphorus sources, respectively, for the production of lipids. On day 14, the maximum lipid concentration of $77.5 \mathrm{mgL}^{-1}$ was produced using optimized culture conditions. Additionally, the maximum number of $17 \times 10^{5}$ cells $\mathrm{mL}^{-1}$ and the biomass concentration of $0.69 \mathrm{gL}^{-1}$ were achieved on this same day. Finally, the fatty acid composition of the algal lipid was analyzed by gas chromatography/mass spectrometry (GC/MS) analysis.
\end{abstract}

Keywords: Isolation; Identification; Nitzschia; Biomass; Lipid

Contact information: a: Department of Environmental Sciences, Bharathiar University, Coimbatore - 641 046, Tamil Nadu, India; $b$ : Research Centre for Sustainable Process Technology, Faculty of Engineering \& Built Environment, University Kebangsaan Malaysia, 43600 Bangi, Selangor, Malaysia;

*Corresponding authors: micro_rajkumar@yahoo.co.in; sobritakriff@ukm.edu.my

\section{INTRODUCTION}

Microalgae have received much attention as a potential renewable energy source as part of the efforts to mitigate global warming. Microalgae can easily convert solar energy into chemical energy via atmospheric carbon dioxide fixation, which is currently under consideration as a promising raw material for biodiesel production (Spolaore et al. 2006; Chisti 2007; Mata et al. 2010).

In spite of the various advantages microalgae could bring to biodiesel production, their biomass and lipid production cost is relatively very high due to many factors associated with the microalgal cultivation process (Chisti 2013; Singh et al. 2015). To improve the economic feasibility of microalgal cultivation, it will be necessary to identify a suitable microalgal strain and explore its response to different cultivation conditions (Chen et al. 2015; Negi et al. 2015; Singh et al. 2016). Recently, many researchers have worked to optimize various factors, such as nitrogen starvation or limitation (Zhila et al. 2005; Jiang et al. 2012; Pancha et al. 2014), silicon deficiency (Lynn et al. 2000), phosphate limitation (Mandal and Mallick 2009; Chu et al. 2013), salinity (Rao et al. 2007; Zhila et al. 2011), pH of the medium (Breuer et al. 2013), iron content (Liu et al. 2008), light intensity (Ruangsomboon 2012), and harvesting time (Zhila et al. 2011), to 
improve the lipid accumulation by microalgae. When evaluating microalgae under such conditions, Hsieh and $\mathrm{Wu}$ (2009) stated that various microalgal strains responded appreciably when the lipid content was increased $30 \%$ to $60 \%$ of the dry cell weight.

The biomass content of the microalgae can be enhanced when the microalgae are cultivated in photobioreactors. A previous study reported that a high concentration of microalgae cultures was cultivated in photobioreactors that facilitate high light intensity surfaces and high mass transfer rates to improve the biomass productivity (Ugwu et al. 2008). It has also been reported that the biomass productivity of Chlorella vulgaris was increased $50 \%$ in the membrane-sparged helical tubular photobioreactor (MSTR) (Fan et al. 2008).

Among these microalgae, diatoms (class Bacillariophyceae) include a large diversity and produce the greatest biomass in the marine environment, though they are not well recognized for biofuel purposes. Diatoms have been identified as promising candidates to produce biodiesel because they give up to $60 \%$ of their cellular biomass as triacylglycerols (TAG) that can be converted into biodiesel through the transesterification process (Blanchemain and Grizeau 1996; Yu et al. 2009). In general, diatoms have been studied widely for their biochemical constituents that can be used for the larval diet in the aquaculture field. However, only a few reports demonstrate the use of diatoms for biofuel production. For example, Nitzschia palea was found to exhibit a high amount of lipid production according to the results given by the Aquatic Species Program (Sheehan et al. 1998).

The effect of nutrients and $\mathrm{pH}$ on marine diatoms, especially Nitzschia sp., for enhancing lipid and biomass production remains an infrequently studied research area. Thus, the present study focused on the isolation of indigenous diatoms from Tuticorin along the Tamil Nadu coast, and studied the effects of cultural conditions on the production of biomass and lipid by the isolate.

\section{EXPERIMENTAL}

\section{Materials}

Isolation and growth conditions

Seawater samples were collected in sterile plastic vials from coastal rock pools in Tuticorin, Tamil Nadu, India. Pure cultures were isolated and purified by streaking $1.5 \%$ agar plates with $\mathrm{F} / 2$ medium (Guillard and Ryther 1962). This media was composed of: $\mathrm{NaNO}_{3}, 75 \mathrm{mgL}^{-1} ; \mathrm{NaH}_{2} \mathrm{PO}_{4} .2 \mathrm{H}_{2} \mathrm{O}, 5 \mathrm{mgL}^{-1}$; $\mathrm{Na}_{2} \mathrm{SiO}_{3} .9 \mathrm{H}_{2} \mathrm{O}, 30 \mathrm{mgL}^{-1}$; trace metal stock solution, $1 \mathrm{~mL}$ (per $1 \mathrm{~L}$ : $\mathrm{FeCl}_{3} .6 \mathrm{H}_{2} \mathrm{O}, 3.15 \mathrm{~g}$; $\mathrm{Na}_{2} \mathrm{EDTA}_{2} .2 \mathrm{H}_{2} \mathrm{O}, 4.36 \mathrm{~g} ; 1 \mathrm{~mL} \mathrm{CuSO}{ }_{4} .5 \mathrm{H}_{2} \mathrm{O}$, $9.8 \mathrm{gL}^{-1} ; 1 \mathrm{~mL} \mathrm{Na}_{2} \mathrm{MoO}_{4} .2 \mathrm{H}_{2} \mathrm{O}, 6.3 \mathrm{gL}^{-1} ; 1 \mathrm{~mL} \mathrm{ZnSO}_{4} .7 \mathrm{H}_{2} \mathrm{O}, 22.0 \mathrm{gL}^{-1} ; 1 \mathrm{~mL} \mathrm{CoCl}_{2} .6 \mathrm{H}_{2} \mathrm{O}$, $10.0 \mathrm{gL}^{-1}$ and $1 \mathrm{~mL} \mathrm{MnCl}_{2} .4 \mathrm{H}_{2} \mathrm{O}, 180.0 \mathrm{gL}^{-1}$ ), and $0.5 \mathrm{~mL}$ of vitamin stock solution (per 1 $\mathrm{L}$ : vitamin B1, $200 \mathrm{mg} ; 1 \mathrm{~mL}$ vitamin $\mathrm{H}, 1.0 \mathrm{gL}^{-1}$ and $1 \mathrm{~mL}$ vitamin $\mathrm{B} 12,1 \mathrm{gL}^{-1}$ ). Media chemicals were bought from Himedia, Mumbai, India. The individual colonies were inoculated into the above liquid medium and incubated at $25 \pm 1{ }^{\circ} \mathrm{C}$ in a thermostatically controlled room, with a light intensity of $30 \mu \mathrm{Em}^{-2} \mathrm{~s}^{-1}$, and a photoperiod of 16:8 h (light: dark). The same cultivation conditions were maintained for all the subsequent experiments. Preliminary identification was made for morphological characteristics under a microscope (John et al. 2003; Bellinger and Sigee 2010). The purity of the individual culture was confirmed by repeated streaking techniques on the nutrient agar plate. Based on the highest lipid productivity and growth rate, the strain was chosen for further study. 


\section{Nile Red Staining}

Nile Red (9-(Diethylamino)-5H-benzo[a]phenoxazin5-one) (Himedia, Mumbai, India) staining was performed to observe intracellular lipid droplets according to the method of Greenspan et al. (1985). Isolated algal cells were cultured for two weeks and tested with Nile Red staining. The growing culture $(0.5 \mathrm{~mL})$ was taken by centrifugation at $1500 \times \mathrm{g}$ for $10 \mathrm{~min}$ and cleaned with a physiological saline solution $(0.5 \mathrm{~mL})$. Once the obtained cells were re-suspended in the same saline solution $(0.5 \mathrm{~mL})$, the Nile Red solution $\left(0.1 \mathrm{mg} \mathrm{mL}^{-1}\right.$ dissolved in acetone) was further added to cell suspensions (1:100 $\mathrm{v} / \mathrm{v}$ ) and kept for $10 \mathrm{~min}$. Subsequently, stained algal cells were observed under fluorescent microscopy.

\section{Molecular Identification}

The selected algal strain of approximately $50 \mathrm{~mL}$ in the log to stationary phase was used for molecular identification. The isolation of the genomic DNA of the microalgal strain was performed using a plant genomic DNA isolation kit (Sigma-Aldrich, Bangalore, India) following the manufacturer's protocol. The primers SSU-1+ (AAC CTG GTT GAT CCT GCC AGT) and SSU-B (CCT TCT GCA GGT TCA CCT AC) (Sigma-Aldrich, Bangalore, India) were subjected to the polymerase chain reaction (PCR) (Medlin et al. 1988; Li et al. 2015). The polymerase chain reaction (PCR) amplification was performed in a thermal cycler (Agilent Technologies, Santa Clara, CA, USA) using the following program: initial denaturation for $5 \mathrm{~min}$ at $95{ }^{\circ} \mathrm{C} ; 20$ cycles for $1 \mathrm{~min}$ at $94{ }^{\circ} \mathrm{C}, 45 \mathrm{~s}$ at $55^{\circ} \mathrm{C}$, $4 \mathrm{~min}$ at $72{ }^{\circ} \mathrm{C}$; and a final extension for $10 \mathrm{~min}$ at $72{ }^{\circ} \mathrm{C}$. Electrophoresis was performed with $1 \%$ agarose gel (Himedia, Mumbai, India) to separate the PCR products. The amplified product was sequenced at Acme Progen Biotech Pvt. Ltd., Salem, Tamil Nadu, India, and the obtained sequences were analyzed on the National Center for Biotechnology Information (NCBI, Bethesda, MA, USA) server using the Basic Local Alignment Search Tool (BLAST). Further, the nucleotide sequence was submitted to the NCBI to obtain the accession number.

\section{Effect of pH, Salinity, Nutrients, and Cultivation Time on Biomass and Lipid Production}

For all experiments, the selected microalgae were grown in an F/2 medium adjusted with different $\mathrm{pH}$ ranges (6 to 9). For the analysis of salinity tolerance, the isolated culture was transferred into the same medium added with $0 \%, 3 \%, 6 \%$, and $9 \%$ of the $\mathrm{NaCl}$ concentration. The effect was $0,18.75,28.125,37.5$, and $46.875 \mathrm{mgL}^{-1}\left(\mathrm{NaNO}_{3}\right.$ as nitrogen source). Quantities of $0,2.32,3.48,5$, and $7 \mathrm{mgL}^{-1}\left(\mathrm{NaH}_{2} \mathrm{PO}_{4}\right.$ as the phosphorus source) were also tested separately. Other than the above cultural parameters, the composition of other elements was the same as the F/2 medium. Experiments were carried out in $500 \mathrm{~mL}$ Erlenmeyer flasks containing $200 \mathrm{~mL}$ medium. All the flasks were inoculated with the $10 \%$ $\mathrm{v} / \mathrm{v}$ cells of two-week-old culture and incubated in a thermostatically controlled room for 16 days to analyze the growth and lipid productivity every 2 days. The optimum cultural parameter was selected at each experiment based on lipid productivity, and further cultivation was completed in a photobioreactor under the optimized conditions.

\section{Cultivation in Photobioreactor}


The chosen microalga was cultivated in a photobioreactor (Lark Innovative Fine Teknowledge, Chennai, India) (2 L capacity) within an optimized F/2 medium to determine the effect of selective factors (Fig. 1).

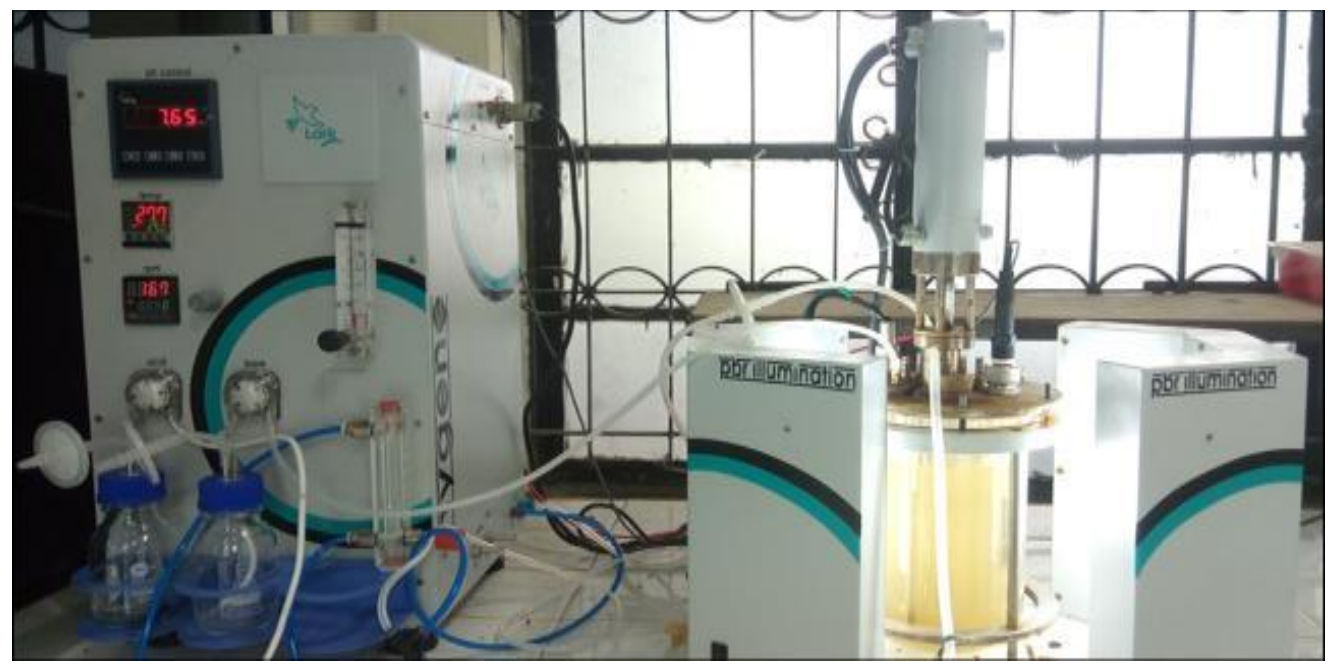

Fig. 1. Photograph of the photobioreactor for the cultivation of Nitzschia sp. RRSE2

The photobioreactor provided a shaft that prevented the culture from settling. Sparger supplied $\mathrm{CO}_{2}$ with air. Turbines helped to mix the media and culture. A glass vessel was autoclaved and used to grow the Nitzschia sp., which was helpful in the overall increase in both biomass and lipid content. For this experiment, $10 \%$ of the inoculum was added to the F/2 media ( $\mathrm{pH} 8$ ) with optimized components, such as a salinity of $3 \%$, a nitrate concentration of $18.75 \mathrm{mgL}^{-1}\left(\mathrm{NaNO}_{3}\right)$, and a concentration of phosphorous of 3.48 $\mathrm{mgL}^{-1}\left(\mathrm{NaH}_{2} \mathrm{PO}_{4}\right)$. The reactor ran until the decline of the growth phase of the algae, which was up to 14 days. The $\mathrm{pH}$ was controlled to remain between 7.9 and 8.1. To maintain a level of $5 \% \mathrm{CO}_{2}$ and to supplement nutrients, the sample was mixed at $150 \mathrm{rpm}$. The conditions surrounding the reactor were a light: dark maintained as $16: 8 \mathrm{~h}$, with 2500 to 3000 lux of light, and a temperature of approximately 25 to $27{ }^{\circ} \mathrm{C}$. A sample of approximately $30 \mathrm{~mL}$ was collected every 2 days starting from day 0 . The cell concentration and the lipid content were recorded during the cultivation process. On day 14, the grown biomass was collected by filtering with Whatman No.1 filter paper. The collected biomass was oven-dried dried at $65^{\circ} \mathrm{C}$ for $1 \mathrm{~h}$, and the crude lipid was extracted. Finally, the extracted lipid was subjected to gas chromatography/mass spectrometry (GC/MS) analysis.

\section{Analytical Methods}

Growth and biomass estimation

The cultures were harvested by centrifugation at $10000 \mathrm{rpm}$ for $5 \mathrm{~min}$. Then, the cells were washed twice with distilled water, and the pellet was dried at $70{ }^{\circ} \mathrm{C}$ for $1 \mathrm{~h}$. The dry weight of the biomass was determined gravimetrically. The algal growth was expressed in terms of dry cell weight (DCW) per liter $\left(\mathrm{gL}^{-1}\right)$. Meanwhile, microalgal growth was also monitored by the cell-counting method using a Neubauer hemocytometer (Rohem, India). 


\section{Extraction and estimation of lipid}

Lipids were extracted from the biomass using the method of Folch et al. (1957). Ten $\mathrm{mL}$ of grown culture was centrifuged. Then, the pellet was collected and ground with chloroform:methanol (1:2, v/v). Physiological saline was added for phase separation between chloroform and methanol. The above experiment was left overnight. The lower chloroform phase was collected and air-dried. The presence of lipid was treated with the concentrated sulphuric acid and kept at a high temperature for $10 \mathrm{~min}$. Then, vanillin reagent was added to the solution and read at $520 \mathrm{~nm}$. Cholesterol (Himedia, Mumbai, India) with different concentrations was used to prepare for the standard graph to find the unknown weight of the isolated lipid. Simultaneously, transesterification of fatty acids was done by the method of Ichihara et al. (1996). The extracted lipid was air dried at room temperature and the obtained lipid was measured gravimetrically. About $10 \mathrm{mg}$ of lipid was dissolved using $2 \mathrm{~mL}$ of hexane and $200 \mu \mathrm{L}$ of $2 \mathrm{M}$ methanolic $\mathrm{KOH}$ and vortexed for 2 to $5 \mathrm{~min}$. The FAME containing upper layer (hexane phase) was recovered for further analysis.

\section{Analysis of fatty acid methyl esters}

Fatty acid methyl esters were analyzed from the extracted lipid by GC/MS according to the method of Tadashi et al. (2009). Gas chromatography/mass spectrometry was performed for the isolated crude lipid and was run in SQ8C GC/MS (Perkin Elmer, Waltham, MA, USA). The crude lipid underwent the basic principle of separation of compounds present in the sample in DB-5ms capillary standard non-polar column $(30 \mathrm{~m}$ length; $0.32 \mathrm{~mm} ; 0.25 \mathrm{~mm}$; with a flow rate of $0.25 \mu \mathrm{m}$ ). A sample of $1 \mathrm{~mL}$ was injected. The oven's initial temperature was $150{ }^{\circ} \mathrm{C}$ and progressively raised to $240{ }^{\circ} \mathrm{C}$. A total of 2 $\mu \mathrm{L}$ of sample was injected with flame ionisation detector (FID) temperature of $260^{\circ} \mathrm{C}$. The nitrogen carrier gas was used as a stationary phase that serves as a column with the solvent delay of $3 \mathrm{~min}$. Retention time, a time at which each particular component eluted from the sample, helped in differentiating the elements. Lastly, the GC/MS analysis of this fatty acid composition was performed at Tamil Nadu Agricultural University, Coimbatore, India.

\section{Statistical analysis}

Statistical analyses were performed using SPSS version 20.0 (IBM Corporation, USA) for one-way ANOVA test. All the experiments were carried out in triplicate. Experimental data were calculated as mean $\pm \mathrm{SE}$, and the mean values were determined by using DMRT (Duncan's Multiple Range Test). Significant differences were considered to be at $\mathrm{P}<0.05$.

\section{RESULTS AND DISCUSSION}

\section{Isolation and Identification of the Isolate}

Nitzschia sp. RRSE2 strain, which was the dominant microalga at the collection site, was isolated from coastal rock pools in Tuticorin by serial dilution, then subjected to plating techniques. The strain revealed the following morphological characteristics under a light microscope: that it was comprised of single cells with bilateral symmetry and isopolar frustules, and in each cell there were two chloroplasts, elongated valves, and a rounded polar end. The cell length was $18.5 \mu \mathrm{m}$, and the width was $4.5 \mu \mathrm{m}$ (Fig. 2a). Nile Red staining of algal cells was also performed to detect intracellular lipid droplets stained 
in red using fluorescence microscopy (Fig. 2b). The strain was identified as genus Nitzschia, confirmed by $18 \mathrm{~S}$ rDNA gene sequencing followed by BLAST analysis, demonstrating over 95\% similarity with other Nitzschia sp. (KT072977.1). Hence, the strain was identified as Nitzschia sp. RRSE2 and the sequences were submitted to the NCBI, and an accession number (MK785417) was obtained.
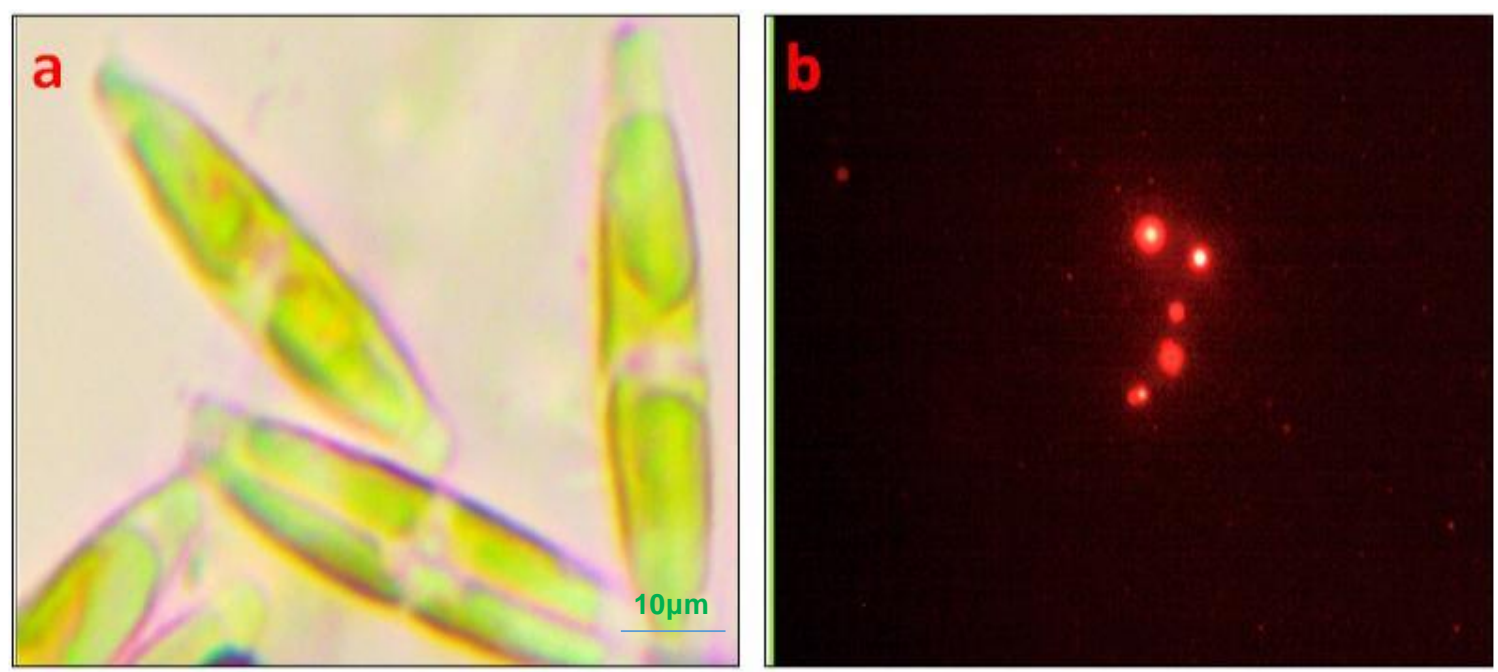

Fig. 2. Microscopy images of the alga, Nitzschia sp. RRSE2 grown on F/2 medium: (a) light microscopic (40x) image of the morphology of Nitzschia sp. RRSE2; (b) fluorescence images of Nitzschia sp. RRSE2 stained with Nile Red

\section{The Effect of pH on Growth and Lipid Production}

Diatoms are a highly diverse group of organisms in nature. They can also grow well in a designated medium with a sufficient amount of nutrients and suitable environmental conditions. Wang et al. (2010) reported that microalgal growth is controlled by various factors such as $\mathrm{pH}$, nutrient availability, size of the seed culture, etc. The F/2 medium supported the growth of different kinds of microalgal species and was used to cultivate the Nitzschia in the present study. The growth curves, biomass, and lipid concentrations of Nitzschia were evaluated under different $\mathrm{pH}$, and are shown in Fig. 3. The growth of Nitzschia demonstrated an optimal growth rate at $\mathrm{pH} 8$ with a maximum cell number of $8.7 \times 10^{5}$ cells $\mathrm{mL}^{-1}$ on the tenth day (Fig. 3a). The maximum biomass content $0.36 \mathrm{gL}^{-1}$ with total lipid productivity of $46.5 \mathrm{mgL}^{-1}$ was observed at $\mathrm{pH} 8$ (Fig. $3 \mathrm{~b}$ and $3 \mathrm{c}$ ). The biomass and lipid content increased until the twelfth day, and no further increment was noticed subsequently. It was thus concluded that Nitzschia was able to tolerate a wide range of $\mathrm{pH}$, an observation that accorded with the reports of Barinova et al. (2011) concerning Fragilaria vaucheriae, and the reports of Li et al. (2017) concerning Synedra sp. and Navicula. The diatom of the present study, Nitzschia, did not grow well in a medium with a lower $\mathrm{pH}$ (acidic conditions) to produce frustules and uptake silicic acid (Martin-Jezequel et al. 2000).

\section{The Effect of Salinity on Growth and Lipid Production}

To study salinity tolerance, Nitzschia was subjected to a wide range of salinity gradients. Increasing the salinity of algal cultures can be used to keep cultures free of unwanted algal species (Chaffin et al. 2011). As shown in Fig. 4, Nitzschia was the fastest growing alga at $6 \% \mathrm{NaCl}\left(9.1 \times 10^{5}\right.$ cells $\left.\mathrm{mL}^{-1}\right)$ with a biomass content of $0.32 \mathrm{gL}^{-1}$ on the day 12 , followed by $9 \%$ and $3 \%$ concentrations. 

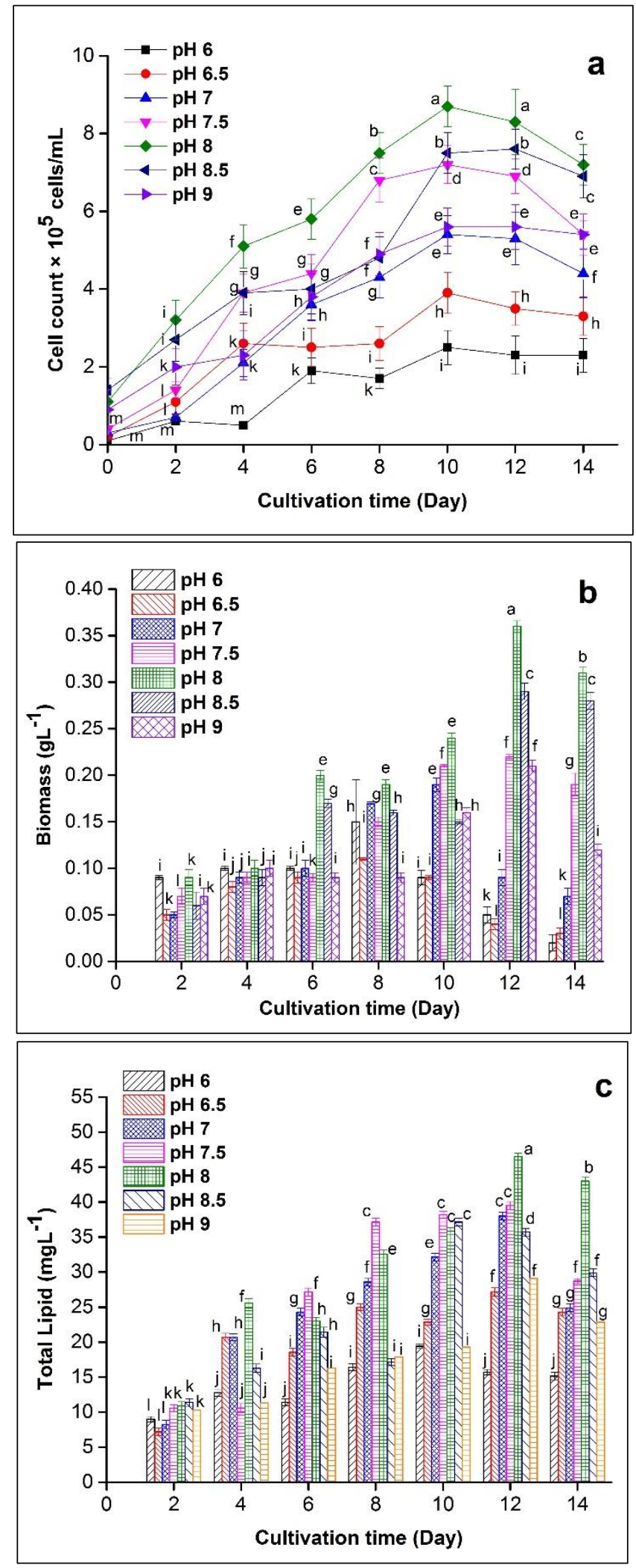

Fig. 3. The effect of $\mathrm{pH}$ on (a) cell growth, (b) biomass concentration, and (c) lipid concentration of Nitzschia sp. RRSE2 grown in F/2 medium. Lines and bars are represent $\pm S E(n=3)$. Means with different small letters on the lines and bars are significantly different $(p<0.05)$. 

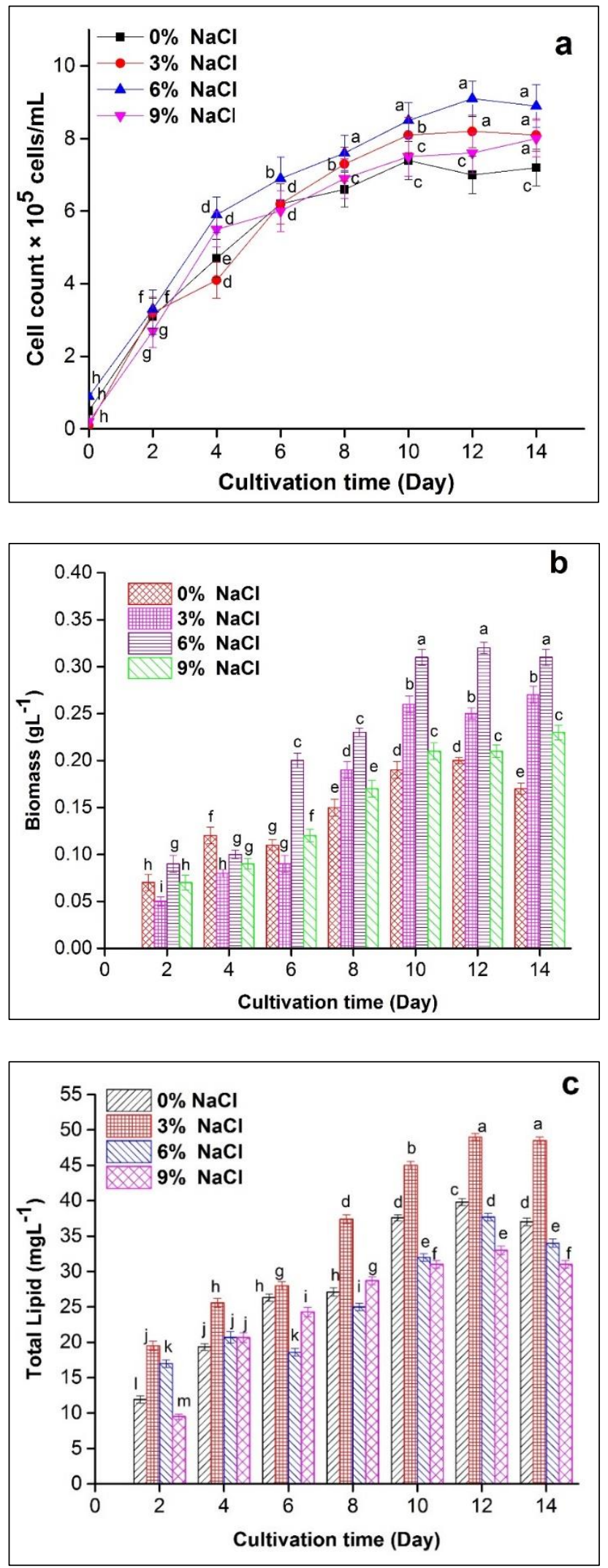

Fig. 4. The effect of $\mathrm{NaCl}$ concentration on (a) cell growth, (b) biomass concentration, and (c) lipid concentration of Nitzschia sp. RRSE2. Lines and bars are represent \pm SE $(n=3)$. Means with different small letters on the lines and bars are significantly different $(p<0.05)$. 
Jahnke and White (2003) stated that decreasing marine microalga growth was observed at a low salinity level. However, in the present study, the highest lipid production of $49 \mathrm{mgL}^{-1}$ was observed at low salinity $(3 \% \mathrm{NaCl})$, followed by $0 \%, 6 \%$, and $9 \% \mathrm{NaCl}$ (Fig. 4a through c). Hu (2004) found that an increase in salt concentration may slightly enhance the total lipid content of algae. Ben-Amotz et al. (1985) stated that low salinity stress also increases the lipid content in Botryococcus braunii.

\section{The Effect of Nitrogen Concentration on Growth and Lipid Production}

The cell growth, the concentration of biomass, and lipid were observed, as depicted in Fig. 5. Although the level of lipid concentration increased with decreased $\mathrm{NaNO}_{3}$ concentration in the culture medium, it varied according to the cell concentration and biomass content (Fig. 5a through c). The maximum biomass concentration of $0.44 \mathrm{gL}^{-1}$ was observed after supplying $37.5 \mathrm{mgL}^{-1} \mathrm{NaNO}_{3}$ to the culture medium on day 14, and the maximum lipid productivity of $58.2 \mathrm{mgL}^{-1}$ was seen at a concentration of $18.75 \mathrm{mgL}^{-1}$ $\mathrm{NaNO}_{3}$ on day 12. Similarly, Yu et al. (2009) reported that the diatom Phaeodactylum tricornutum (FACHB-863) grown in a complete F/2 medium produced biomass equaling $530 \mathrm{mgL}^{-1}$.

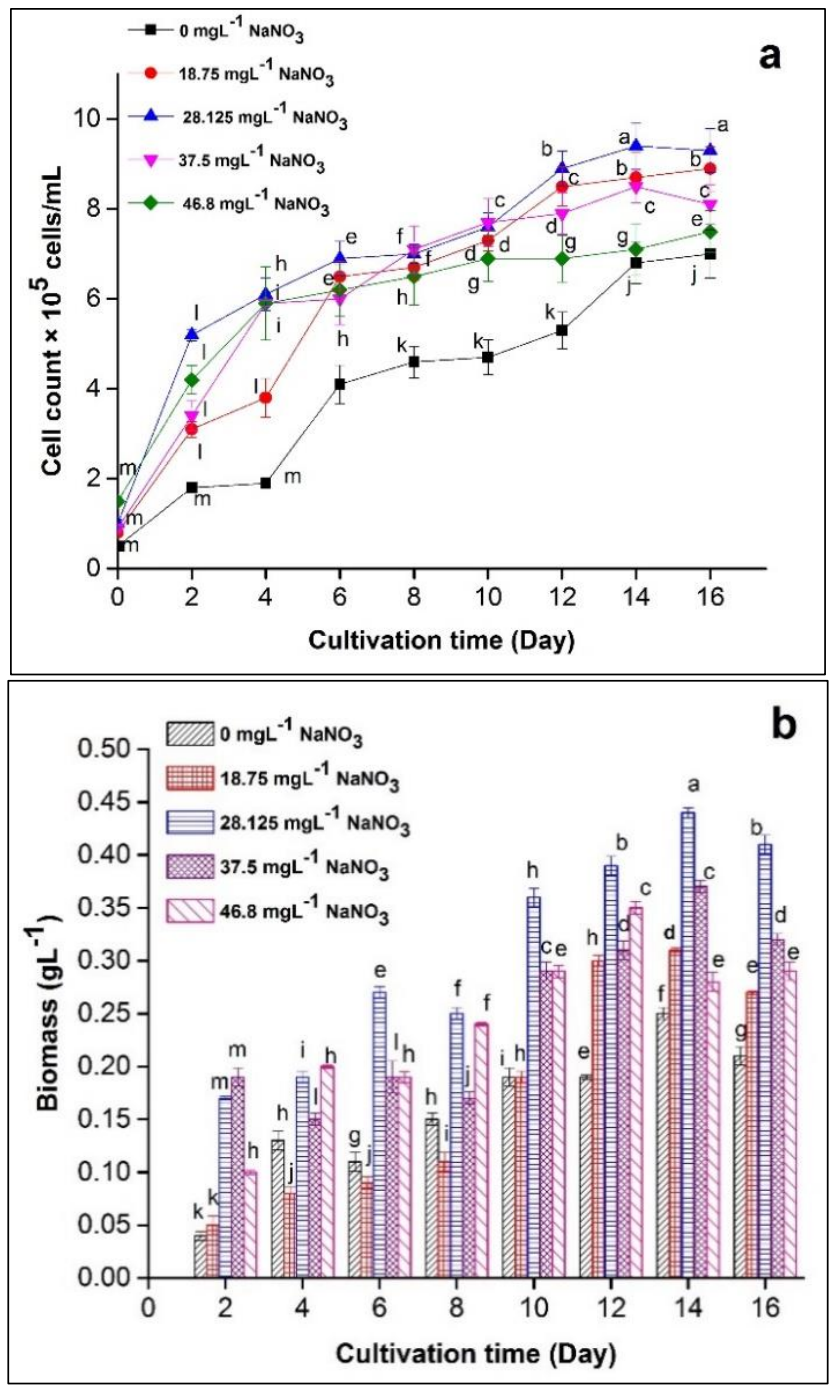




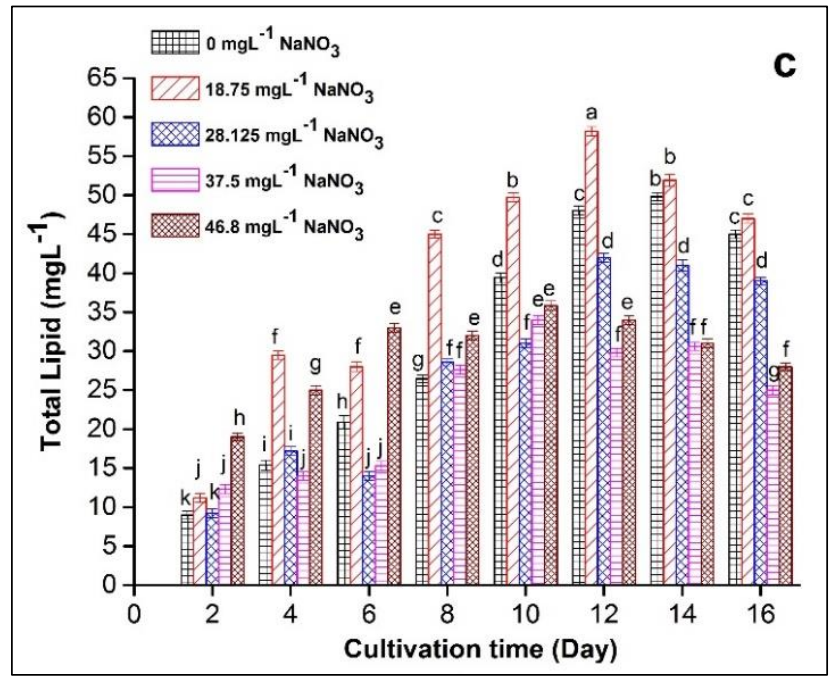

Fig. 5. The effect of $\mathrm{NaNO}_{3}$ concentration on (a) cell growth, (b) biomass concentration, and (c) lipid concentration of Nitzschia sp. RRSE2. Lines and bars are represent $\pm S E(n=3)$. Means with different small letters on the lines and bars are significantly different $(p<0.05)$.

The results of the previous study accorded with previous reports by Tornabene $e t$ al. (1983) and Lv et al. (2010), which demonstrated that a green alga produces higher lipid content at a lower $\mathrm{NaNO}_{3}$ concentration. Converti et al. (2009) reported that a lack of nitrogen limits protein synthesis and hence increases lipid content and, sometimes, the accumulation of carbohydrates in the cells (Hu 2003).

\section{The Effect of Phosphorus Concentration on Growth and Lipid Production}

Across microalgae species, phosphorous is among the essential nutrient components of the medium in cellular metabolic processes. The effects of different phosphorus concentrations on cell growth, biomass, and lipid concentration are given in Fig. 6a through c. The highest biomass production and cell number of $0.51 \mathrm{gL}^{-1}$ and 13.4 $\times 10^{5}$ cells $\mathrm{mL}^{-1}$ were obtained at the increased phosphorus concentration of $5 \mathrm{mgL}^{-1}$. The biomass and cell numbers increased when the phosphorus concentration in the medium increased, but the lipid content decreased. The maximum lipid concentration of $56 \mathrm{mgL}^{-1}$ was recorded with a phosphorus concentration of $3.48 \mathrm{mgL}^{-1}$ in the medium, because phosphate is a vital nutrient for the cell growth and development (excepting lipid yield). Mandal and Mallick (2009) reported that growing Scenedesmus obliquus had an increment of lipid only under phosphorus-deficient conditions.

\section{Performance of Microalga Growth and Lipid Production with Photobioreactor Using Optimized F/2 Medium}

The preliminary investigation made on Nitzschia under different culture conditions revealed that the optimal conditions for enhanced production of total lipids were: (1) $\mathrm{pH}$ 8.0 , (2) $3 \% \mathrm{NaCl}$ concentration, (3) $18.75 \mathrm{mgL}^{-1} \mathrm{NaNO}_{3}$, and (4) $3.48 \mathrm{mgL}^{-1} \mathrm{NaH}_{2} \mathrm{PO}_{4}$ in $\mathrm{F} / 2$ medium (other components are fixed amounts). The isolate Nitzschia grown under the above conditions for 16 days in $2 \mathrm{~L}$ of medium were subjected to cultivation in a photobioreactor, with special attention to the estimation of total lipid and biomass content. Photobioreactors have been used to produce increased algal biomass and even specific molecules, such as lipids (Ugwu et al. 2008; Rodolfi et al. 2009). 

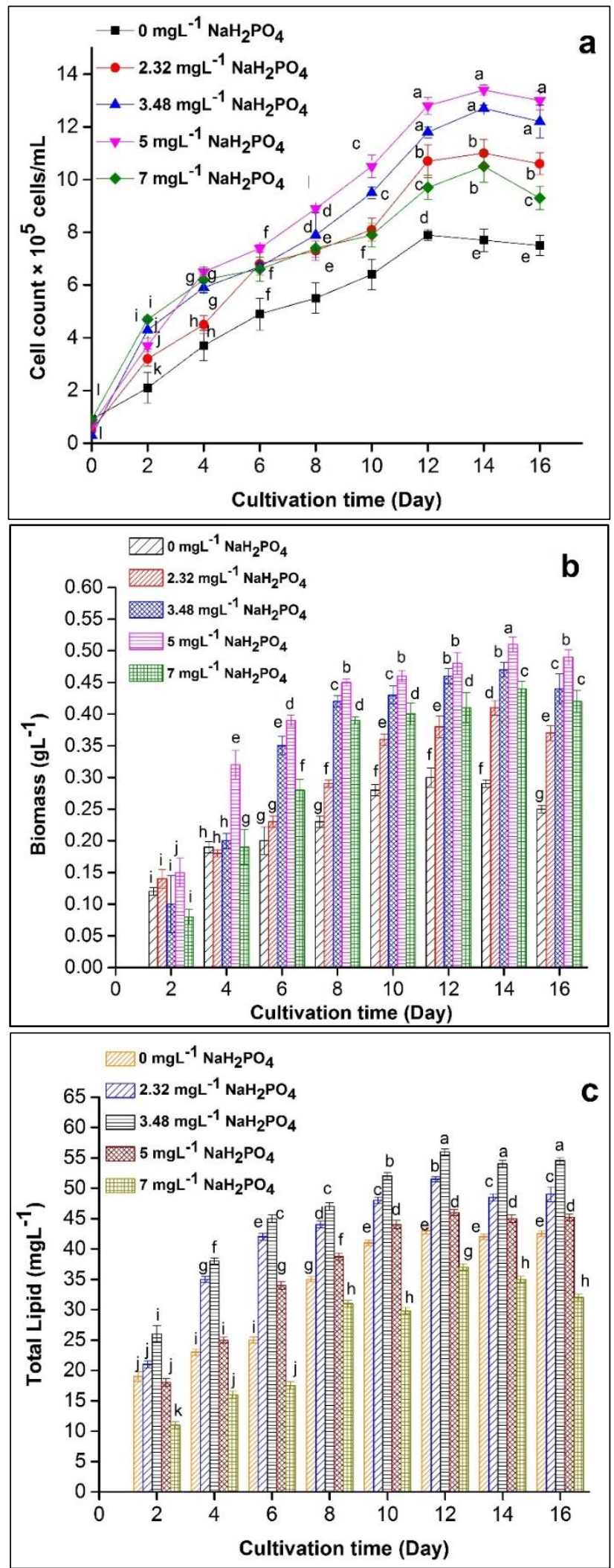

Fig. 6. The effect of $\mathrm{NaH}_{2} \mathrm{PO}_{4}$ concentration on (a) cell growth, (b) biomass concentration, and (c) lipid concentration of Nitzschia sp. RRSE2. Lines and bars are represent $\pm S E(n=3)$. Means with different small letters on the lines and bars are significantly different $(p<0.05)$. 

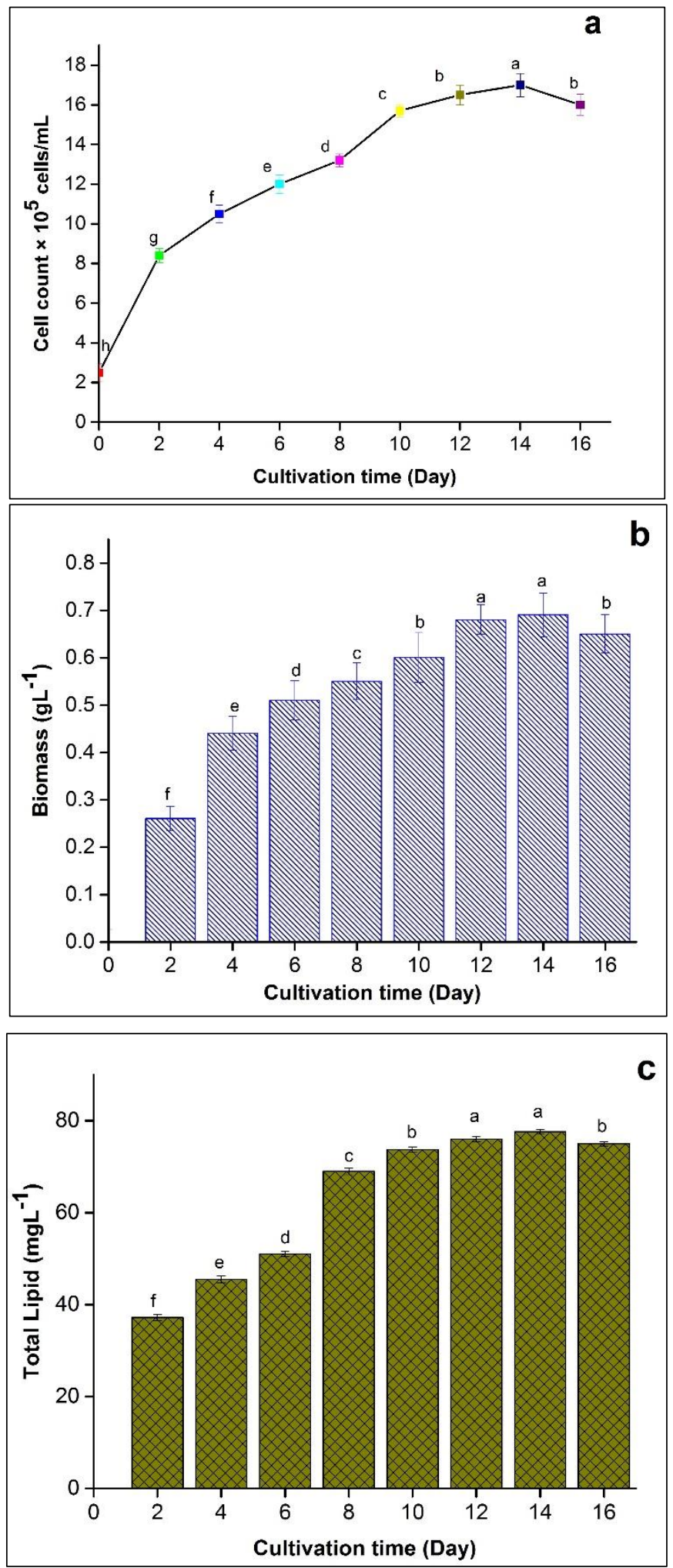

Fig. 7. Cultivation of Nitzschia sp. RRSE2 in a $2 \mathrm{~L}$ photobioreactor using optimized $F / 2$ medium on the effect of (a) cell growth, (b) biomass concentration, and (c) lipid concentration. Lines and bars are represent \pm SE $(n=3)$. Means with different small letters on the lines and bars are significantly different $(p<0.05)$. 
It was noteworthy that the results of culturing in the photobioreactor showed the yield of biomass and lipid comparatively higher $\left(0.69 \mathrm{gL}^{-1}\right.$ biomass and $77.5 \mathrm{mgL}^{-1}$ on day 14) than in the shake flask culture (Fig. 7a through c). The maximum number of cells $17 \times$ $10^{5}$ cells $\mathrm{mL}^{-1}$ was also recorded on day 14; subsequently, it decreased. The availability of surface area and aeration in the reactor may have been the reason for producing more biomass and lipid.

The present findings are in similarity with those of Arroussi et al. (2017). They reported that Nitzschia produced biomass up to $0.82 \mathrm{gL}^{-1}$ in the culture medium F/2 supplemented with silicate. Also, in their study, the diatom strains such as Amphora, Chaetoceros and Navicula were also reached biomass level up to $0.5 \mathrm{gL}^{-1}$. Regarding the lipid content, a nearly 1.7 fold increment was seen in lipid when cultures grown under photobioreactor with optimized medium.

Though the biomass and growth rate is the limiting factor for large scale production of biodiesel in an economic point of view, it has been stated that algal growth can be in inverse proportion to lipid content (Griffiths and Harrison 2009; Rodolfi et al. 2009). It may be varied species to species. This study Nitzschia had an increasing lipid content across the production stage is considered to be significant indicator for biodiesel production.

\section{The Fatty Acid Profile of Nitzschia sp. RRSE2 Cultivated in Optimized F/2 Medium}

The diatom was grown in a photobioreactor for the extraction of crude lipid, and it was analyzed by GC/MS to confirm the presence of biodiesel components as presented in Fig. 8. Biodiesel is composed of mainly fatty acid methyl esters, which is derived by the transesterification of produced lipids (Wackett 2008). This author also reported that the quality of biodiesel is significantly affected by the fatty acid components presented in the biodiesel.

In addition to that, differences in the carbon chain length and the unsaturation degree are the important characteristics of biodiesel (Griffiths et al. 2009). Table 1 shows that the precursor of biodiesel present in the crude extract viz., decane, octane, nonane, and undecane derivatives, with its following percentages: n-dodecanoic acid (lauric acid (C12:0)) with 10.56\%, tetradecanoic acid (myristic acid (C14:0)) with $9.44 \%$, hexadecanoic acid (palmitic acid (C16:0)) with 19.58\%, 9-cis-hexadecenoic acid (palmitoleic acid (C16:1)) with 12.9\%, octadecanoic acid (stearic acid (C18:0)) with 14.96\%, (9Z,12Z,15Z)-octadeca-9,12,15-trienoic acid (linolenic acid (C18:3)) with 14.8\% and $(Z$ )-docos-13-enoic acid (erucic acid (C22:1)) with 5.9\%, respectively. The presence of high ratio of octadecanoic acid shows that the compound is presented from the biodiesel transesterified in crude lipid of Nitzschia sp. RRSE2. These observations are in agreement with an earlier report, which stated that the presence of $12 \%$ linolenic acid is acceptable for the quality biodiesel (Arroussi et al. 2017; Purkan et al. 2019). It has been reported that the components such as palmitic, oleic, stearic, linoleic and linolenic acid were considered as the most common fatty acids in biodiesel by Knothe (2008).

According to Gao et al. (2013), a lipid with a high content of saturated and monounsaturated fatty acids with a low amount of polyunsaturated fatty acids are essential for the production of biodiesel. Therefore, extensive studies are required to determine the fatty acid distribution of Nitzschia sp. RRSE2. 
Table 1. Compounds Present in Lipid Extracted from Nitzschia sp. RRSE2

\begin{tabular}{|c|c|c|c|}
\hline No. & $\begin{array}{l}\text { Retention } \\
\text { Time }\end{array}$ & $\begin{array}{c}\text { Area } \\
(\%)\end{array}$ & Components \\
\hline 1. & 4.41 & 1.156 & $\begin{array}{c}\text { Decane; decane, 2,5,6-trimethyl-; undecane; } \\
\text { octane, 3,5-dimethyl-; nonane, 2-methyl-; nonane; } \\
\text { octane, 4-ethyl-, decane, 2,6,8-trimethyl-; octane, 4- } \\
\text { methyl-, dodecane, 6-methyl- }\end{array}$ \\
\hline 2. & 12.21 & 1.230 & $\begin{array}{c}\text { 2,4-di-tert-butylphenol; phenol, 2,5-bis(1,1-- } \\
\text { dimethylethyl)-; phenol, 3,5-bis(1,1-dimethylethyl)-; } \\
\text { pentanoic acid, 5-hydroxy-, 2,4-di-t-butylphenyl } \\
\text { esters; phenol, 2,6-bis(1,1-dimethylethyl)-; } \\
\text { pentanedioic acid, (2,4-di-t-butylphenyl) mono- } \\
\text { ester;phenol,4-(1,1-dimethylethyl)-2-(1,1- } \\
\text { dimethylpropyl)-; silane, [4-(1,1- } \\
\text { dimethylethyl)phenyl]trimethyl-; 7,9-di-tertbutyl-1- } \\
\text { oxaspiro[4,5]deca-6,9-dien-8-one; ethyl 4-t- } \\
\text { butylbenzoate }\end{array}$ \\
\hline 3. & 16.20 & 3.960 & $\begin{array}{l}\text { Methanone, (1-hydroxycyclohexyl)penyl-; 2-benzoyl- } \\
\text { 8-octanelactam; cyclohexanol, 1-(2-hexenyl)-; } \\
\text { androst-5-en-17one, 2-spiro-2'-1,3-dopxalane-, 2,2'- } \\
\text { bioxepane, (2-aminocyclohexyl)-phenyl-methanol; } \\
\text { (3,4-dimethoxyphenyl)-hydroxy-phenylacetic acid, 1- } \\
\text { methylpiperidin-4-ylester; cyclohexaneethanol, 1- } \\
\text { hydroxy-a-nitro-; 1-methyl-f-piperidyl 2-(3,5- } \\
\text { dimethoxyphenyl)-2-2hydroxy-2-phenylacetate }\end{array}$ \\
\hline 4. & 20.77 & 1.459 & $\begin{array}{l}\text { Diphenylsulfone; 5-phenoxymethyl-furan-2- } \\
\text { carboxylic acid; pyracarbolid; 2-propenenitrile, 2- } \\
\text { (phenylsulphonyl)-; 1,2-bis(phenylsulfonl)ethane; 2- } \\
\text { propenoid acid, 3-(phenylsulfonyl)-, methyl ester; } \\
\text { benzene, (1-propenylsulfonyl)-, (E)-; benzene, } \\
\text { (ethylsulfonyl)-; [(dibromomethyl)sulfonyl]benzene; } \\
\text { bis[phenylsulfonyl]-4-carboxyl phenyl methane }\end{array}$ \\
\hline 5. & 22.01 & 2.211 & $\begin{array}{c}\text { 5,8,11-heptadecatriyonoic acid, methyl ester; 1,6- } \\
\text { jeptadoeme, 2-methyl-6-phenyl-; 10- } \\
\text { oxytricyclo[6.4.0.09,12]dodecane-9-carboxylic acid, } \\
\text { 11-oxo-12-phenyl-methyl ester; panaxynone; } \\
\text { benzene, 1-methyl-3,5-bis(3-methyl-3-butenyl)-; 1- } \\
\text { phenylbicyclo(4.1.0), heptane; } \\
\text { tricyclo[7.4.0.0(3,8)]tridec-12-en-2-one, 5,6-epoxy-4- } \\
\text { methyl-1-(2-propynyl)-; benzene, 1,3,5-tris(3-methyl- } \\
\text { 3-betenyl)-; 5-methyl-1-phenyl } \\
\text { bicyclo[3.2.0]heptane; cyclohexane, 2-(2-nitro-1- } \\
\text { phenyl-2-propenyl)- }\end{array}$ \\
\hline
\end{tabular}




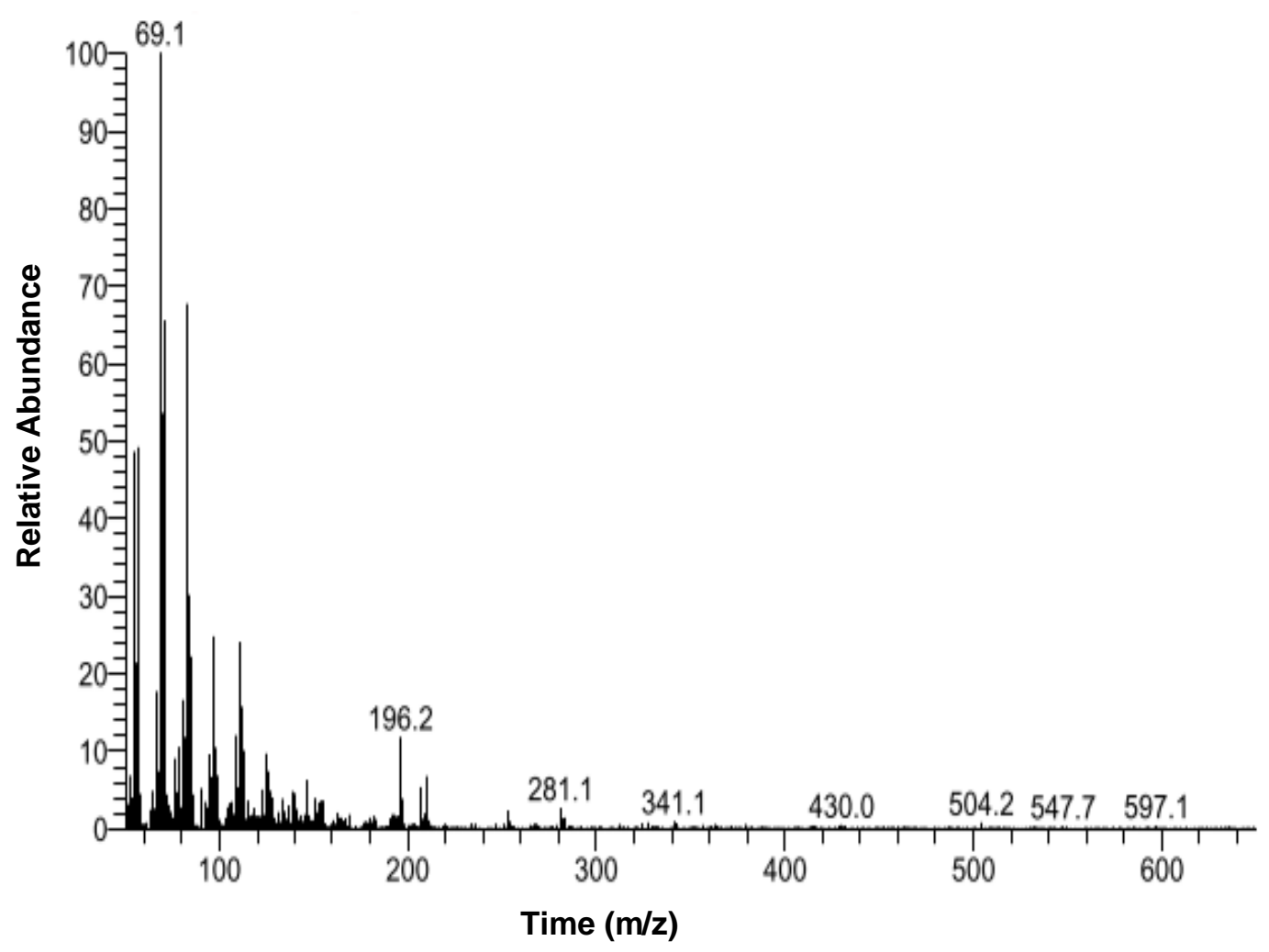

Fig. 8. Gas chromatogram of fatty acid profile extracted from Nitzschia sp. RRSE2

\section{CONCLUSIONS}

1. A maximum lipid concentration was observed in the conditions of $\mathrm{pH} 8,3 \% \mathrm{NaCl}$, $18.75 \mathrm{mgL}^{-1}$ nitrogen source, $3.48 \mathrm{mgL}^{-1} \mathrm{NaH}_{2} \mathrm{PO}_{4}$, and in the $\mathrm{F} / 2$ medium.

2. Increased lipid productivity was observed when the alga was cultured and when the nitrogen source was of a low concentration.

3. Gradual increment of lipid (1. 7 fold) was observed in photobioreactor using optimized medium when compared to initial culturing.

4. The GC/MS profile confirmed that the presence of suitable components which are essential for biodiesel production.

5. This study indicated that this indigenous microalga can be cultivated in saltwater medium and it may be adopted to coastal belt for large scale cultivation, thereby avoiding demand for fresh water.

\section{ACKNOWLEDGEMENTS}

The authors gratefully acknowledge financial support from the Science \& Engineering Research Board (SERB), Department of Science and Technology, Government of India (Project number: YSS/2015/001217), and the University Kebangsaan Malaysia (Grant code: FRGS/2018/TK02), Malaysia. 


\section{REFERENCES CITED}

Arroussi, H. E., Benhima, R., Mernissi, N. E., Bouhfid, R., Tilsaghani, C., Bennis, I., and Wahby, I. (2017). "Screening of marine microalgae strains from Moroccan coasts for biodiesel production," Renewable Energy 113, 1515-1522. DOI:

10.1016/j.renene.2017.07.035

Barinova, S., Kukhaleishvili, L., Nevo, E., and Janelidze, Z. (2011). "Diversity and ecology of algae in the Algeti National Park as a part of the Georgian system of protected areas," Turkish Journal of Botany 35(6), 729-774. DOI: 10.3906/bot-1009-83

Bellinger, E. G., and Sigee, D. C. (2010). Freshwater Algae: Identification and Use as Bioindicators, Wiley-Blackwell, Chichester, UK.

Ben-Amotz, A., Tornabene, T. G., and Thomas, W. H. (1985). "Chemical profile of selected species of microalgae with emphasis on lipids," Journal of Phycology 21(1), 72-81. DOI: 10.1111/j.0022-3646.1985.00072.x

Blanchemain, A., and Grizeau, D. (1996). "Eicosapentaenoic acid content of Skeletonema costatum as a function of growth and irradiance; relation with chlorophyll $a$ content and photosynthetic capacity," Journal of Experimental Marine Biology and Ecology 196 (1-2), 177-188. DOI: 10.1016/0022-0981(95)00129-8

Breuer, G., Lamers, P. P., Martens, D. E., Draaisma, R. B., and Wijffels, R. H. (2013). "Effect of light intensity, $\mathrm{pH}$, and temperature on triacylglycerol (TAG) accumulation induced by nitrogen starvation in Scenedesmus obliquus," Bioresource Technology 143, 1-9. DOI: 10.1016/j.biortech.2013.05.105

Chaffin, J. D., Mishra, S., Kuhaneck, R. M., Heckathorn, S. A., and Bridgeman, T. B. (2011). "Environmental controls on growth and lipid content for the freshwater diatom, Fragilaria capucina: A candidate for biofuel production," Journal of Applied Phycology 24(5), 1045-1051. DOI: 10.1007/s10811-011-9732-X

Chen, Y., Tang, X., Kapoore, R. V., Xu, C., and Vaidyanathan, S. (2015). "Influence of nutrient status on the accumulation of biomass and lipid in Nannochloropsis salina and Dunaliella salina," Energy Conversion and Management 106, 61-72. DOI: 10.1016/j.enconman.2015.09.025

Chisti, Y. (2007). "Biodiesel from microalgae," Biotechnology Advances 25(3), 294-306. DOI: 10.1016/j.biotechadv.2007.02.001

Chisti, Y. (2013). "Constraints to commercialization of algal fuels," Journal of Biotechnology 167(3), 201-214. DOI: 10.1016/j.jbiotec.2013.07.020

Chu, F. F., Chu, P. N., Cai, P. J., Li, W. W., Lam, P. K. S., and Zeng, R. J. (2013). "Phosphorus plays an important role in enhancing biodiesel productivity of Chlorella vulgaris under nitrogen deficiency," Bioresource Technology 134, 341346. DOI: 10.1016/j.biortech.2013.01.131

Converti, A., Casazza, A. A., Ortiz, E. Y., Perego, P., and Del Borghi, M. (2009). "Effect of temperature and nitrogen concentration on the growth and lipid content of Nannochloropsis oculata and Chlorella vulgaris for biodiesel production," Chemical Engineering and Processing: Process Intensification 48(6), 1146-1151. DOI: 10.1016/j.cep.2009.03.006

Fan, L. H., Zhang, Y. T., Zhang, L., and Chen, H. L. (2008). "Evaluation of a membranesparged helical tubular photobioreactor for carbon dioxide biofixation by Chlorella vulgaris," Journal of Membrane Science 325(1), 336-345. DOI:

10.1016/j.memsci.2008.07.044 
Folch, J., Lees, M., and Sloane-Stanley, G. H. S. (1957). "A simple method for the isolation and purification of total lipids from animal tissue," The Journal of Biological Chemistry 226, 497-509.

Gao, Y., Yang, M., and Wang, C. (2013). "Nutrient deprivation enhances lipid content in marine microalgae," Bioresource Technology 147, 484-491. DOI:

10.1016/j.biortech.2013.08.066

Greenspan, P., Mayer, E. P., and Fowler, S. D. (1985). "Nile red: A selective fluorescent stain for intracellular lipid droplets," Journal of Cell Biology 100(3), 965-973. DOI: 10.1083/jcb.100.3.965

Griffiths, M. J., and Harrison, S. T. L. (2009). "Lipid productivity as a key characteristic for choosing algal species for biodiesel production," Journal of Applied Phycology 21(5), 493-507. DOI: 10.1007/s10811-008-9392-7

Guillard, R. R., and Ryther, J. H. (1962). "Studies of marine planktonic diatoms: I. Cyclotella nana Hustedt, and Detonula confervacea (cleve) gran," Canadian Journal of Microbiology 8(2), 229-239. DOI: 10.1139/m62-029

Hsieh, C. H., and Wu, W. T. (2009). "Cultivation of microalgae for oil production with a cultivation strategy of urea limitation," Bioresource Technology 100(17), 39213926. DOI: 10.1016/j.biortech.2009.03.019

$\mathrm{Hu}$, Q. (2003). “Environmental effects on cell composition,” in: Handbook of Microalgal Culture: Biotechnology and Applied Phycology,A. Richmond (ed.),Wiley-Blackwell, Hoboken, NJ, USA, pp. 83-94. DOI: 10.1002/9780470995280.ch5

Ichihara, K., Shibahara, A., Yamamoto, K., and Nakayama, T. (1996). "An improved method for rapid analysis of the fatty acids of glycerolipids," Lipids 31, 535-539. DOI: $10.1007 / \mathrm{BF} 02522648$

Jahnke, L. S., and White, A. L. (2003). "Long-term hyposaline and hypersaline stresses produce distinct antioxidant responses in the marine alga Dunaliella tertiolecta," Journal of Plant Physiology 160(10), 1193-1202. DOI: 10.1078/0176-1617-01068

Jiang, Y., Yoshida, T., and Quigg, A. (2012). "Photosynthetic performance, lipid production and biomass composition in response to nitrogen limitation in marine microalgae," Plant Physiology and Biochemistry 54, 70-77. DOI: 10.1016/j.plaphy.2012.02.012

John, D. M., Whitton, B. A., and Brook, A. J. (2003). The Freshwater Algal Flora of the British Isles: An Identification Guide to Freshwater and Terrestrial Algae Cambridge University Press, Cambridge, UK, pp. 287-389. DOI: 10.5860/choice.40-3394

Knothe, G. (2008). "Designer biodiesel: Optimizing fatty ester composition to improve fuel properties," Energy Fuels 22(2), 1358-1364. DOI: 10.1021/ef700639e

Li, C. L., Ashworth, M. P., Witkowski, A., Dazbek, P., Medlin, L. K., Kooistra, W. H. C. F., Sato, S., Zglobicka, I., and Kurzydłowski, K. J. (2015). "New insights into Plagiogrammaceae (Bacillariophyta) based on multigene phylogenies and morphological characteristics with the description of a new genus and three new species," PLoS ONE 10(10), e0139300. DOI: 10.1371/journal.pone.0139300

Li, X., Marella, T. K., Tao, L., Li, R., Tiwari, A., and Li, G. (2017). “Optimization of growth conditions and fatty acid analysis for three freshwater diatom isolates," Phycological Research 65(3), 177-187. DOI: 10.1111/pre.12174

Liu, Z. Y., Wang, G. C., and Zhou, B. C. (2008). "Effect of iron on growth and lipid accumulation in Chlorella vulgaris," Bioresource Technology 99 (11), 4717-4722. DOI: 10.1016/j.biortech.2007.09.073 
Lv, J. M., Cheng, L. H., Xu, X. H., Zhang, L., and Chen, H. L. (2010). "Enhanced lipid production of Chlorella vulgaris by adjustment of cultivation conditions," Bioresource Technology 101(17), 6797-6804. DOI: 10.1016/j.biortech.2010.03.120

Lynn, S. G., Kilham, S. S., Kreeger, D. A., and Interlandi, S. J. (2000). "Effect of nutrient availability on the biochemical and elemental stoichiometry in fresh water diatom Stephanodiscus minutulus Bacillariophyceae," Journal of Phycology 36(3), 510-522. DOI: 10.1046/j.1529-8817.2000.98251.x

Mandal, S., and Mallick, N. (2009). "Microalga Scenedesmus obliquus as a potential source for biodiesel production," Applied Microbiology and Biotechnology 84(2), 281-291. DOI: 10.1007/s00253-009-1935-6

Martin-Jezequel, V., Hildebrand, M., and Brzezinski, M. A. (2000). "Silicon metabolism in diatoms: Implications for growth," Journal of Phycology 36(5), 821-840. DOI: 10.1046/j.1529-8817.2000.00019.x

Mata, T. M., Martins, A. A., and Caetano, N. S. (2010). "Microalgae for biodiesel production and other applications: A review," Renewable and Sustainable Energy Reviews 14(1), 217-232. DOI: 10.1016/j.rser.2009.07.020

Medlin, L., Elwood, H. J., Stickel, S., and Sogin, M. L. (1988). "The characterization of enzymatically amplified eukaryotic 16S-like rRNA-coding regions," Gene 71, 491499. DOI: 10.1016/0378-1119(88)90066-2

Negi, S., Barry, A. N., Friedland, N., Sudasinghe, N., Subramanian, S., Pieris, S., Holguin, F. O., Dungan, B., Schaub, T., and Sayre, R. (2015). "Impact of nitrogen limitation on biomass, photosynthesis, and lipid accumulation in Chlorella sorokiniana," Journal of Applied Phycology 28, 803-812. DOI: 10.1007/s10811-0150652-z

Pancha, I., Chokshi, K., George, B., Ghosh, T., Paliwal, C., Maurya, R., and Mishra, S. (2014). "Nitrogen stress triggered biochemical and morphological changes in the microalgae Scenedesmus sp. CCNM 1077," Bioresource Technology 156, 146-154. DOI: 10.1016/j.biortech.2014.01.025

Purkan, P., Nidianti, E., Abdulloh, A., Safa, A., Retnowati, W., Soemarjati, W., Nurlaila, H., and Kim, S. W. (2019). "Biodiesel production by lipids from Indonesian strain of microalgae Chlorella vulgaris," Open Chemistry 17, 919-926. DOI: $10.1515 /$ chem-2019-0102

Rao, A. R., Dayananda, C., Sarada, R., Shamala, T. R., and Ravishankar, G. A. (2007). "Effect of salinity on growth of green alga Botryococcus braunii and its constituents," Bioresource Technology 98(3), 560-564. DOI: 10.1016/j.biortech.2006.02.007

Rodolfi, L., Zitelli, G. C., Bassi, N., Padovani, G., Biondi, N., Bonini, G., and Tredici, M. (2009). "Microalgae for oil: Strain selection, induction of lipid synthesis and outdoor mass cultivation in a low-cost photobioreactor," Biotechnology and Bioengineering 102(1), 100-112. DOI: 10.1002/bit.22033

Ruangsomboon, S. (2012). "Effect of light, nutrient, cultivation time and salinity on lipid production of newly isolated strain of the green microalga, Botryococcus braunii KMITL 2," Bioresource Technology 109, 261-265. DOI: 10.1016/j.biortech.2011.07.025

Sheehan, J., Dunahay, T., Benemann, J., and Roessler, P. (1998). A Look Back at the U.S. Department of Energy's Aquatic Species Program - Biodiesel from Algae (NREL/TP-580-24190), National Renewable Energy Laboratory, Golden, CO, USA.

Singh, P., Guldhe, A., Kumari, S., Rawat, I., and Bux, F. (2015). "Investigation of combined effect of nitrogen, phosphorus and iron on lipid productivity of microalgae 
Ankistrodesmus falcatus KJ671624 using response surface methodology," Biochemical Engineering Journal 94, 22-29. DOI: 10.1016/j.bej.2014.10.019

Singh, P., Kumari, S., Guldhe, A., Misra, R., Rawat, I., and Bux, F. (2016). "Trends and novel strategies for enhancing lipid accumulation and quality in microalgae," Renewable and Sustainable Energy Reviews 55, 1-16. DOI: 10.1016/j.rser.2015.11.001

Spolaore, P., Joannis-Cassan, C., Duran, E., and Isambert, A. (2006). "Commercial applications of microalgae," Journal of Bioscience and Bioengineering 101(2), 8796. DOI: $10.1263 / \mathrm{jbb} .101 .87$

Tornabene, T. G., Holzer, G., Lien, S., and Burris, N. (1983). "Lipid composition of the nitrogen starved green alga Neochloris oleoabundans," Enzyme and Microbial Technology 5(6), 435-440. DOI: 10.1016/0141-0229(83)90026-1

Ugwu, C. U., Aoyagi, H., and Uchiyama, H. (2008). "Photobioreactors for mass cultivation of algae,” Bioresource Technology 99(10), 4021-4028. DOI: 10.1016/j.biortech.2007.01.046

Wackett, L. P. (2008). "Biomass to fuels via microbial transformations," Current Opinion in Chemical Biology 12(2), 187-193. DOI: 10.1016/j.cbpa.2008.01.025

Wang, L., Li, Y., Chen, P., Min, M., Chen, Y., Zhu, J., and Ruan, R. R. (2010). "Anaerobic digested dairy manure as a nutrient supplement for cultivation of oil-rich green microalgae Chlorella sp.," Bioresource Technology 101(8), 2623-2628. DOI: 10.1016/j.biortech.2009.10.062

Yu, E. T., Zendejas, F. J., Lane, P. D., Gaucher, S., Simmons, B. A., and Lane, T. W. (2009). "Triacylglycerol accumulation and profiling in the model diatoms Thalassiosira pseudonana and Phaeodactylum tricornutum (Bacillariophyceae) during starvation," Journal of Applied Phycology 21, 669-681. DOI: 10.1007/s10811-008-9400-y

Zhila, N. O., Kalacheva, G. S., and Volova, T. G. (2005). "Influence of nitrogen deficiency on biochemical composition of the green alga Botryococcus," Journal of Applied Phycology 17, 309-315. DOI: 10.1007/s10811-005-7212-X

Zhila, N. O., Kalacheva, G. S., and Volova, T. G. (2011). "Effect of salinity on the biochemical composition of the alga Botryococcus braunii Kutz IPPAS H-252," Journal of Applied Phycology 23(1), 47-52. DOI: 10.1007/s10811-010-9532-8

Article submitted: May 15, 2020; Peer review completed: July 15, 2020; Revised version received: August 5, 2020; Accepted: August 9, 2020; Published: August 13, 2020. DOI: $10.15376 /$ biores.15.4.7532-7550 